OPEN ACCESS

International Journal of

Environmental Research and

Public Health

ISSN 1660-4601

www.mdpi.com/journal/ijerph

Article

\title{
Variations of Soil Lead in Different Land Uses Along the Urbanization Gradient in the Beijing Metropolitan Area
}

\author{
Qizheng Mao ${ }^{1, \dagger}$, Ganlin Huang ${ }^{1, \dagger}$, Keming Ma ${ }^{2, *}$ and Zexiang Sun ${ }^{1}$
}

1 Center for Human-Environment System Sustainability (CHESS), State Key Laboratory of Earth Surface Processes and Resource Ecology (ESPRE), Beijing Normal University, Beijing 100875, China; E-Mails: maoqizhenger@126.com (Q.M.); ghuang@bnu.edu.cn (G.H.); kindsnake@126.com (Z.S.)

2 State Key Laboratory of Systems Ecology, Research Center for Eco-Environmental Sciences, Chinese Academy of Sciences, Beijing 100085, China

$\dagger$ These authors contributed equally to this work.

* Author to whom correspondence should be addressed; E-Mail: mkm@rcees.ac.cn; Tel./Fax: +86-10-6284-9104.

Received: 4 January 2014; in revised form: 17 February 2014 / Accepted: 17 February 2014 / Published: 18 March 2014

\begin{abstract}
Understanding the spatial pattern of soil lead $(\mathrm{Pb})$ levels is essential to protecting human health. Most previous studies have examined soil $\mathrm{Pb}$ distributions by either urbanization gradient or land-use type. Few studies, however, have examined both factors together. It remains unclear whether the impacts of land use on soil $\mathrm{Pb}$ levels are consistent along the urbanization gradient. To fill this gap, we investigated variations in soil $\mathrm{Pb}$ level under different land-use types along the urbanization gradient in Beijing, China. We classified the degree of urbanization as the urban core, transitional zone, or suburban area and the land-use type as industrial area, roadside, residential area, institutional area, road greenbelt, park, or forest. Our results showed that the range of soil $\mathrm{Pb}$ levels in Beijing is $<1 \mathrm{mg} / \mathrm{kg}-292 \mathrm{mg} / \mathrm{kg}$, with a mean of $22 \mathrm{mg} / \mathrm{kg}$. Along the urbanization gradient, the mean soil $\mathrm{Pb}$ level increased from the suburban area to the urban core. Land-use types have an impact on soil $\mathrm{Pb}$ levels, however, when the degree of urbanization is considered, the impact from land use on soil $\mathrm{Pb}$ level was only significant in the transitional zone. Parks and road greenbelts were found to have lower soil $\mathrm{Pb}$, primarily due to soil restoration. Roadside and residential areas were found to have higher
\end{abstract}


soil $\mathrm{Pb}$ because of traffic emissions, leaded paint, and previous industrial contamination. In the urban core and suburban area, the soil $\mathrm{Pb}$ level showed no significant differences among various land-use types. Given the results of soil $\mathrm{Pb}$ in various land-use types, we suggest that future studies consider the urbanization gradient in which different land-use samples are located.

Keywords: soil $\mathrm{Pb}$; urbanization gradient; land use; Beijing

\section{Introduction}

Lead $(\mathrm{Pb})$ exposure has adverse effects on human health [1,2], especially for young children. Low-dose $\mathrm{Pb}$ exposure can cause long-term effects on central nervous system functioning and brain development in children [3,4]. Soil is an important pathway of human $\mathrm{Pb}$ exposure [5]. The blood $\mathrm{Pb}$ levels of young children have been strongly correlated with the soil $\mathrm{Pb}$ levels in their neighborhood environment [6], therefore, understanding soil $\mathrm{Pb}$ patterns is crucial for identifying $\mathrm{Pb}$ sources and communities at risk of lead poisoning.

The spatial pattern of soil $\mathrm{Pb}$ pollution levels has been studied extensively. Many studies have examined how soil $\mathrm{Pb}$ level varies by urbanization phase in cities all over the world, including Hong Kong [7,8], Baltimore, New York City, Budapest [9], Bergen [10], Wuhan [11] and Beijing [12]. All of these studies concluded that soil $\mathrm{Pb}$ levels tend to increase with the increasing amount of urbanization.

Researchers found soil metals, in particular $\mathrm{Pb}$, were positively related to intensive urbanization metrics (e.g., urban population density, length of roads and highways, traffic volume, and percent urban land use) [9]. Distance to urban core was a good predictor of soil metals (including $\mathrm{Pb}$ ) relative to the above metrics [9]. Meanwhile, many studies have indicated that urban soil $\mathrm{Pb}$ varied greatly between urban core, transitional zone, and suburban areas $[7,8,13]$.

Other studies have explored whether soil $\mathrm{Pb}$ varies between different land uses in urban areas. Soil $\mathrm{Pb}$ level was found to be higher near roads [14-16], buildings [17], and industrial and business land uses [7,18,19]. However, studies were not consistent regarding the soil $\mathrm{Pb}$ level in parks. For example, parks in Oakland (CA, USA), contained lower soil $\mathrm{Pb}$ levels than residential and industrial areas [20], whereas parks were found to have higher soil $\mathrm{Pb}$ levels than other land-use areas in Beijing, China [12], and Seville, Spain [21]. In Baltimore, (Maryland, USA) the soil Pb level did not differ significantly by land-use area [22].

In studies of urban soil $\mathrm{Pb}$, land-use classification varies by research purpose and data availability. Some studies have classified land use into residential, industrial, commercial, park, forest, and transport regions [19,21-23]. Others surveyed agricultural lands [7,21], urban vacant plots [20,24], ornamental areas [21], institutional green spaces [22], and household gardens [20]. Furthermore, the definition of a certain land use may also change across studies. For example, in 2012 Wang et al. referred to ancient palaces and gardens in Beijing as "parks" [12], by which other studies meant "open space for recreational use" [21] or forests [7]. The inconsistency of land-use classifications and definitions may lead to divergence among studies, which will be discussed later. 
While both urbanization process and land use have been considered when exploring the spatial patterns of soil $\mathrm{Pb}$ levels, few studies have considered both factors at the same time. The parks that McClintock studied in Oakland are distributed throughout the entire city [20]. In contrast, the parks studied in Beijing are primarily located in the urban core area [12]. It remains unclear whether soil $\mathrm{Pb}$ level varies by land-use area when the urbanization gradient is considered. This study aims to fill this gap by analyzing the spatial patterns of soil $\mathrm{Pb}$ level by urbanization gradient and land use in Beijing, China. Specifically, we focus on three questions: (1) How does soil $\mathrm{Pb}$ level vary along the urbanization gradient? (2) How does soil Pb level vary by land-use area? (3) Lastly, considering both the urbanization gradient and land use simultaneously, how does soil $\mathrm{Pb}$ level vary across different land-use areas in the urban core, transitional zone and suburban areas? Answers to these questions will help to articulate the impact of urbanization and land use on the spatial patterns of soil $\mathrm{Pb}$ levels and will contribute to identifying areas with $\mathrm{Pb}$-related health risks.

\section{Materials and Method}

\subsection{Study Area}

We selected the city of Beijing as our study area. Beijing has an area of approximately $16,410 \mathrm{~km}^{2}$ and a population of 20.69 million [25]. Located in the northwestern edge of the North China Plain, Beijing has experienced rapid urban sprawl with homocentric expansion around a ring-road system [26]. Beijing's urban land area increased by a factor of 3.4 from 1984 to 2008 [26]. The degree of urbanization and subsequent variety of land-use types makes Beijing an ideal study site to investigate our study questions.

The main sources of $\mathrm{Pb}$ in Beijing include industry emissions, motor vehicle emissions, coal burning, the long-range dust transported from outside Beijing [27], and leaded paints [12,15]. In Beijing, the zone within 3rd ring road is the heart of city (central business district, hospital, administrative center, public management), also includes the oldest districts (Dongcheng and Xicheng districts) [28], which simultaneously have the most dense traffic network. The zone between the 3rd and 5th ring road is the main residential area [28], parts of which were transferred from industrial areas [26]. The zone between the 5th and 6th road includes the suburbs and the satellite cities, which are developing as the residence-manufacturing zones [28], and the main industrial site, the Shougang Construction Group, is located in this area. Differences in land use and sources of $\mathrm{Pb}$ pollution in Beijing would cause the variability of soil $\mathrm{Pb}$ levels in the different urban zones and land-use types.

\subsection{Sample Collection}

To characterize the urbanization gradient, we sampled along eight transects from the city center to the suburban areas (east, southeast, south, southwest, west, northwest, north, and northeast) and established 78 survey plots at 3-km intervals along these transects, and we define the area within a 500-m radius as a plot. Next, we added 52 additional plots at $6-\mathrm{km}$ intervals to capture the area between the eight transects in more detail. Our study includes 130 plots in total (Figure 1). We recorded the dominant land-use type at each plot. Within each land-use type, one composite 
surface soil sample $(0-20 \mathrm{~cm})$ was obtained by mixing three subsamples diagonally distributed within a representative $20 \mathrm{~m} \times 20 \mathrm{~m}$ open space. A total of 451 soil samples were collected from July to September 2009.

Figure 1. Study area and soil sampling sites.

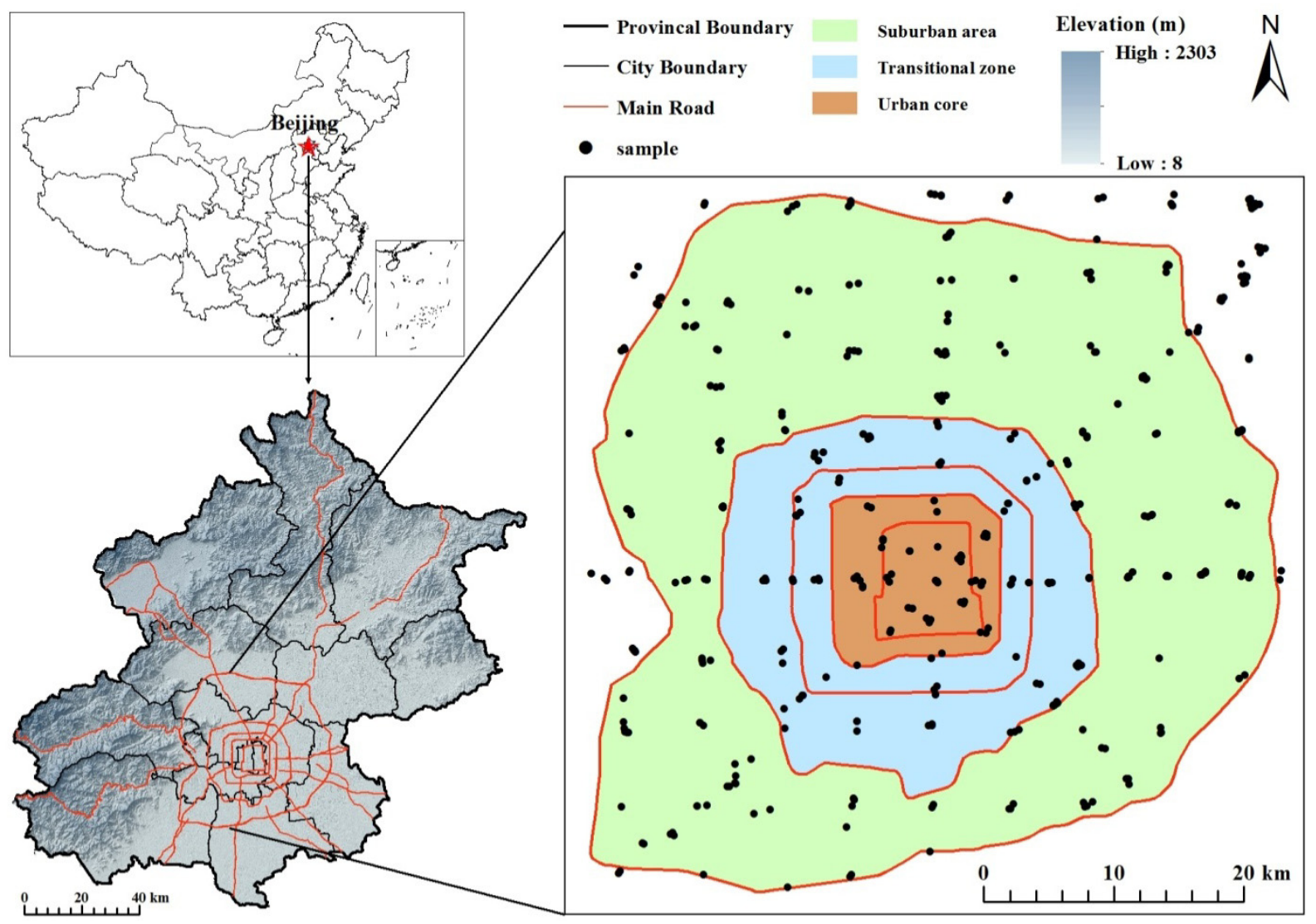

\subsection{Sample Preparation and Instrument Analysis}

The soil samples were stored indoors and dried at room temperature. Debris (e.g., leaves, stones, and worms) were removed by hand. The samples were then ground to pass through a 0.15 -mm nylon sieve. Next, samples were extracted using $\mathrm{HNO}_{3}$ and $\mathrm{HF}$ according to USEPA method 3052 with a microwave laboratory unit [29]. The $\mathrm{Pb}$ content was determined using inductively coupled plasma optical emission spectrometry (ICP-OES). Quality assurance and quality control procedures were conducted using the Geochemical Standard Soil (GSS-1) standard reference materials. In each assay array, we used two GSS-1 samples and ultrapure water as a blank control. The recoveries of soil $\mathrm{Pb}$ in our study were $90 \%-105 \%$ for $\mathrm{Pb}$. A duplicated sample was used for $30 \%$ of the soil samples; the standard deviation of the results was within $\pm 5 \%$.

\subsection{Defining the Urbanization Gradient}

Beijing has five circular express roads, named the 2nd-6th ring roads (Figure 1). Built in 1924, the 1st ring road was merged into other roads and disappeared during the urbanization process [30]. The construction of the ring roads reflects urbanization expansion in Beijing (Table 1). Therefore, the ring roads provide a good measurement of the urban development in Beijing. 
In this study, we define the area within the 3rd ring road as the urban core (number of samples $\mathrm{n}=61$ ), the area between the 3rd and 5th ring roads as the urban transitional zone $(n=92)$, and the area outside the 5 th ring road as the suburban area $(n=298)$ (Table 1, Figure 1).

Table 1. Information of ring roads and urbanization in Beijing.

\begin{tabular}{cccc}
\hline Road & Built Year & Length $\mathbf{( k m )}$ & Enclosed Area $\left.\mathbf{( k m}^{\mathbf{2}}\right)$ \\
\hline 1st ring & Built in early 1900s & 16.9 & 17.7 (within 1st ring) \\
2nd ring & 1992 & 32.38 & 44.4 (between 1st and 2nd ring road) \\
3rd ring & 1994 & 48.24 & 96.17 (between 2nd and 3rd ring road) \\
4th ring & 2001 & 65.19 & 143.3 (between 3rd and 4th ring road) \\
5th ring & 2003 & 98.39 & 364.5 (between 4th and 5th ring road) \\
6th ring & 2009 & 185.82 & 1,580 (Between 5th and 6th ring road) \\
\hline
\end{tabular}

\subsection{Classification of Land Use}

We categorized land use into seven types: residential area, institutional area, industrial area, road greenbelt, roadside, park, and forest. Table 2 provides detailed descriptions of the seven types of land use, and Figure 2 depicts examples of each type.

Table 2. Description of seven typical land use types in the urban area.

\begin{tabular}{cl}
\hline Land Use & \multicolumn{1}{c}{ Description } \\
\hline Forest (55) & Located in suburban area, include large area of managed or \\
& unmanaged woodland (Populus x canadensis) \\
Neighborhood park (55) & Open space for recreational use \\
Residential (76) & Residential buildings and the surrounding neighborhood \\
Industrial (15) & Factories, often located in suburban area \\
Institutional (38) & School, hospital and office building \\
Roadside (101) & Lines of single trees next to road \\
Road greenbelts (111) & Relatively large area of vegetation distributed along road \\
\hline
\end{tabular}

\subsection{Statistical Analysis}

We arranged the raw data in MS Excel 2010 (Microsoft, Redmond, WA, USA) and performed statistical analyses in SPSS 21 (IBM, Armonk, NY, USA). We used the Kolmogorov-Smirnov (K-S) test for normality to determine whether the $\mathrm{Pb}$ data were normally distributed, and the result showed the $\mathrm{Pb}$ data was non-normal. An F-test was conducted to examine whether the soil Pb level varies between different areas. Considering the log-normality of the $\mathrm{Pb}$ data, we employed the multiple comparison with Kruskal-Wallis test to compare soil $\mathrm{Pb}$ levels in different areas. 
Figure 2. The seven types of land use in our study: (a) Road greenbelts; (b) Roadside; (c) Residential area; (d) Neighborhood park; (e) Forest; (f) Industrial area; (g) Institutional sites.
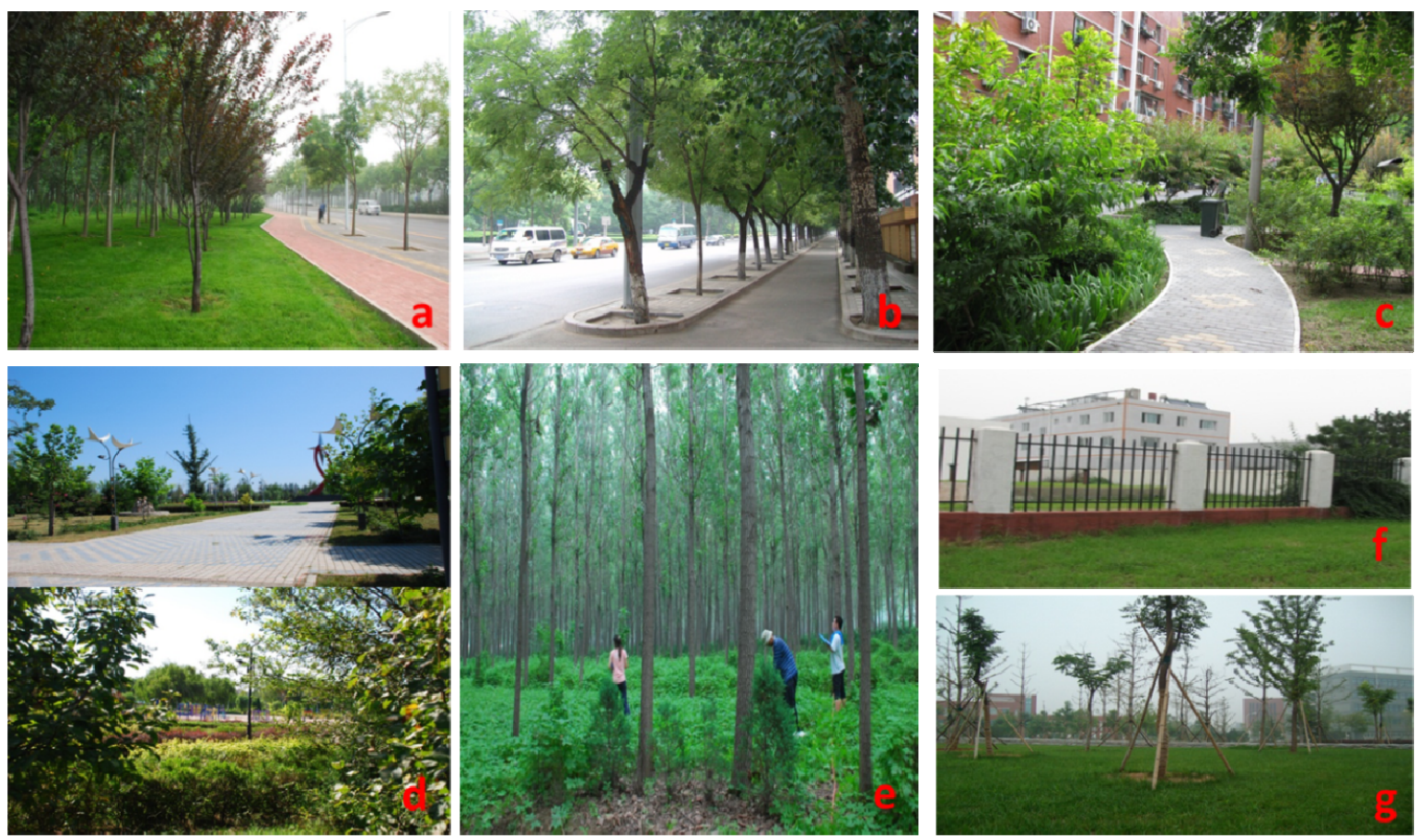

\section{Results}

\subsection{Soil Pb Level along the Urban Gradient}

The results show that the mean $\mathrm{Pb}$ level is $22 \mathrm{mg} / \mathrm{kg}$ (range: $<1$ to $292 \mathrm{mg} / \mathrm{kg}$ ) (Table 3) and increases from the suburban area to the urban core (Table 3, Figure 3).

Figure 3. Box-and-whisker plots for soil $\mathrm{Pb}$ levels along the urbanization gradient.

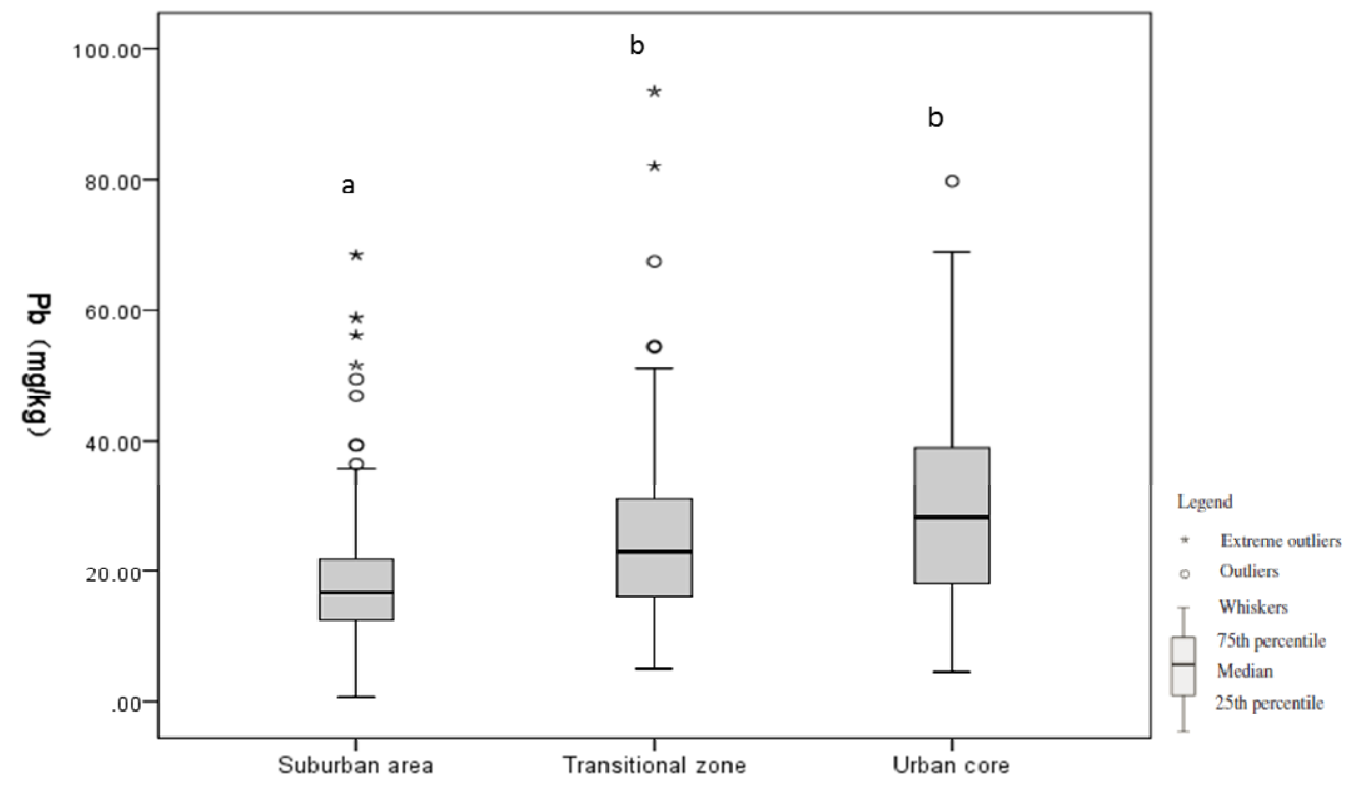

Notes: $a, b$ represent the results of multiple comparisons, and the different letters represent the significant difference between two land use types. 
The mean $\mathrm{Pb}$ level is $19 \mathrm{mg} / \mathrm{kg}$ in the suburban area, $26 \mathrm{mg} / \mathrm{kg}$ in the transitional zone, and $29.56 \mathrm{mg} / \mathrm{kg}$ in the urban core. Our results indicated that the soil $\mathrm{Pb}$ level in the suburban area is lower than those in the urban core and transitional area, and the difference is statistically significant $(P<0.001)$. Although the soil $\mathrm{Pb}$ level in the transitional zone is lower than that in the urban core, the difference is not statistically significant $(P=0.764)$.

Table 3. Descriptive statistic and Kruskal-Wallis Test of soil lead $(\mathrm{mg} / \mathrm{kg})$ for different land uses in urban core, transitional zone and suburban area.

\begin{tabular}{|c|c|c|c|c|c|c|c|c|c|}
\hline Urbanization & Land Use & Industrial & Roadside & Residential & Institutional & $\begin{array}{c}\text { Road } \\
\text { Greenbelts }\end{array}$ & Park & Forest & Total \\
\hline \multirow{5}{*}{ Entire study } & $\mathrm{N}$ & 15 & 101 & 76 & 38 & 111 & 55 & 55 & 451 \\
\hline & Mean & 42 & 25 & 24 & 20 & 19 & 17 & 20 & 22 \\
\hline & Min & 8 & 2 & 4 & 7 & 1 & 5 & 4 & 1 \\
\hline & Max & 292 & 93 & 82 & 69 & 60 & 32 & 52 & 292 \\
\hline & $\begin{array}{c}\text { Multiple } \\
\text { comparisons }\end{array}$ & $a b$ & $\mathrm{a}$ & $a b$ & $a b$ & $\mathrm{~b}$ & $\mathrm{~b}$ & $a b$ & \\
\hline \multirow{5}{*}{ Urban core } & $\mathrm{N}$ & & 14 & 18 & 8 & 16 & 5 & & 61 \\
\hline & Mean & & 34 & 30 & 30 & 27 & 23 & & 30 \\
\hline & Min & & 6 & 5 & 7 & 5 & 16 & & 5 \\
\hline & Max & & 80 & 55 & 69 & 60 & 32 & & 80 \\
\hline & $\begin{array}{c}\text { Multiple } \\
\text { comparisons }\end{array}$ & & $\mathrm{a}$ & $\mathrm{a}$ & $\mathrm{a}$ & $\mathrm{a}$ & $\mathrm{a}$ & & \\
\hline \multirow{5}{*}{$\begin{array}{l}\text { Transitional } \\
\text { zone }\end{array}$} & $\mathrm{N}$ & 4 & 24 & 17 & 8 & 27 & 12 & & 92 \\
\hline & Mean & 33 & 35 & 33 & 23 & 19 & 16 & & 26 \\
\hline & Min & 18 & 11 & 14 & 10 & 8 & 5 & & 5 \\
\hline & Max & 51 & 93 & 82 & 32 & 37 & 29 & & 93 \\
\hline & $\begin{array}{c}\text { Multiple } \\
\text { comparisons }\end{array}$ & $a b$ & $\mathrm{a}$ & $\mathrm{a}$ & $a b$ & $\mathrm{~b}$ & $\mathrm{~b}$ & & \\
\hline \multirow{5}{*}{$\begin{array}{c}\text { Suburban } \\
\text { area }\end{array}$} & $\mathrm{N}$ & 11 & 63 & 41 & 22 & 68 & 38 & 55 & 298 \\
\hline & Mean & 45 & 19 & 18 & 15 & 17 & 16 & 20 & 19 \\
\hline & Min & 8 & 2 & 4 & 7 & 1 & 6 & 4 & 1 \\
\hline & Max & 292 & 49 & 68 & 25 & 59 & 32 & 52 & 292 \\
\hline & $\begin{array}{c}\text { Multiple } \\
\text { comparisons }\end{array}$ & $\mathrm{a}$ & $\mathrm{a}$ & $\mathrm{a}$ & $\mathrm{a}$ & $\mathrm{a}$ & $\mathrm{a}$ & $\mathrm{a}$ & \\
\hline
\end{tabular}

Notes: $a, b$ represent the results of multiple comparisons, and the different letters represent the significant difference between two land use types.

\subsection{Soil Pb Level by Land Use Type}

Table 3 lists the mean $\mathrm{Pb}$ level by land use. The difference in the soil $\mathrm{Pb}$ among the seven land-use types is statistically significant $(P=0.004)$, which suggests that the soil $\mathrm{Pb}$ level varies by land use (Figure 4). The results of multiple comparisons detected statistically significant differences in soil $\mathrm{Pb}$ between roadside and parks $(P=0.006)$ and between roadside and road greenbelts $(P=0.028)$ (Figure 4$)$. 


\subsection{Soil Pb Level by Land-Use Type along the Urbanization Gradient}

Table 3 summarizes the soil $\mathrm{Pb}$ levels by land-use type in the urban core, transitional zone, and suburban area. Soil $\mathrm{Pb}$ levels vary significantly by land use in the transitional zone $(P<0.001)$, whereas the soil $\mathrm{Pb}$ level in the urban core and suburban area do not show any statistically significant differences among land-use types $(P=0.578$ and $P=0.097$, respectively).

Figure 4. Box-and-whisker plots for soil $\mathrm{Pb}$ levels among different land uses.

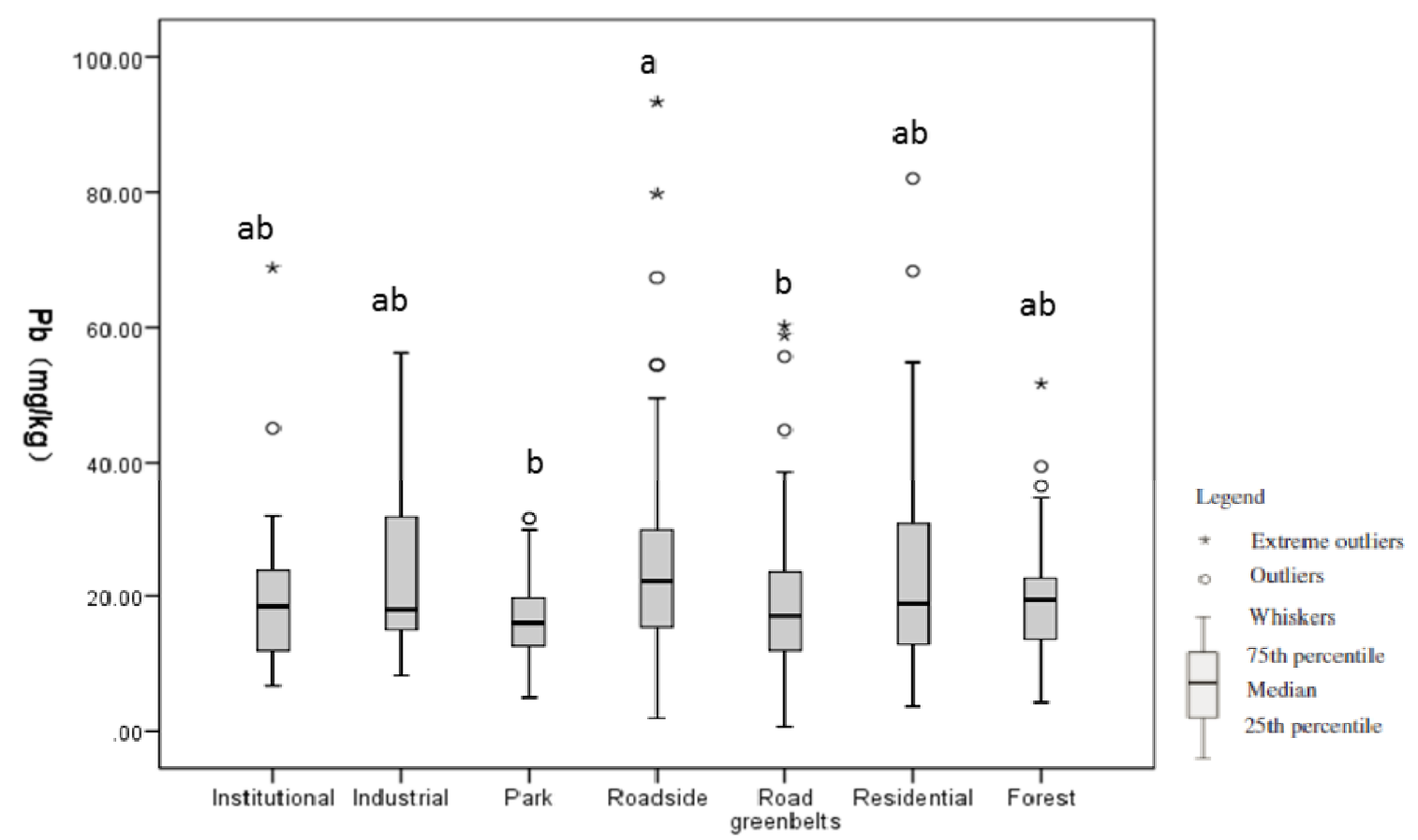

Notes: a, b represent the results of multiple comparisons, and the different letters represent the significant difference between two land use types.

The soil $\mathrm{Pb}$ distribution by land-use type is shown in Figure 5. Significant differences in soil $\mathrm{Pb}$ among various land-use types were detected between parks and roadside $(P=0.003)$, parks and residential areas $(P=0.006)$, road greenbelts and residential areas $(P=0.019)$, and road greenbelts and roadside places $(P=0.007)$.

\section{Discussion}

\subsection{Soil Pb Level in Beijing}

Our study reveals that the mean $\mathrm{Pb}$ level in Beijing is $22 \mathrm{mg} / \mathrm{kg}$. Compared with other studies in Beijing (Table 4), our result is lower than those of studies limited to the 5th ring road $[12,23,31,32]$ and higher than those of studies that include areas outside the 6th ring road [33,34]. The different study areas and sampling approach likely contributes to the variability in soil $\mathrm{Pb}$ levels in different studies. Because soil $\mathrm{Pb}$ levels tend to be higher in more urbanized area, this variability is expected. 
Figure 5. Box-and-whisker plots for soil $\mathrm{Pb}$ levels among different land uses in transitional zone.

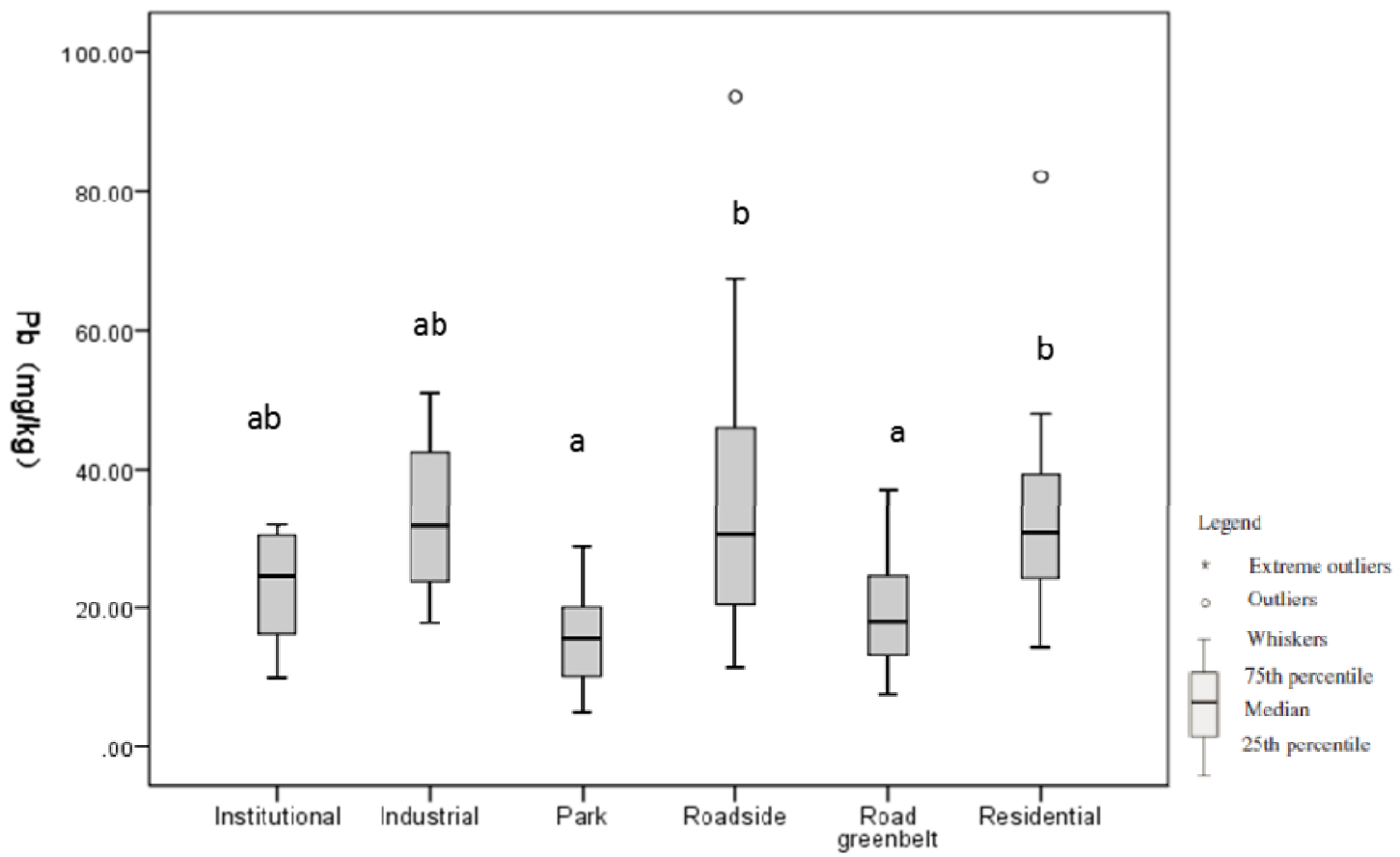

Notes: a, b represent the results of multiple comparisons, and the different letters represent the significant difference between two land use types.

Table 4. Soil $\mathrm{Pb}$ levels according to different studies in Beijing.

\begin{tabular}{|c|c|c|c|c|c|}
\hline Reference & $\begin{array}{c}\text { Mean-Pb } \\
(\mathrm{mg} / \mathrm{kg})\end{array}$ & $\begin{array}{c}\text { Number } \\
\text { of } \\
\text { Samples }\end{array}$ & $\begin{array}{l}\text { Time of } \\
\text { Survey }\end{array}$ & $\begin{array}{l}\text { Location of Study } \\
\text { Area }\end{array}$ & Land Use \\
\hline This study & 22 & 457 & 2009 & $\begin{array}{l}\text { All areas within } 6 \text { th } \\
\text { ring road }\end{array}$ & $\begin{array}{l}\text { Park/residential/institutional/road } \\
\text { greenbelts/roadside/industrial } \\
\text { area/forest }\end{array}$ \\
\hline Hu et al. 2006 [33] & 18.8 & 70 & 2000 & Daxing District & —Not described by authors \\
\hline Lu et al. 2012 [34] & 20.4 & 412 & 2009 & Shunyi District & Agricultural area \\
\hline Wang et al. 2012 [12] & 23.3 & 233 & 2008 & $\begin{array}{l}\text { All areas within } 5 \text { th } \\
\text { ring road }\end{array}$ & $\begin{array}{l}\text { Public parks/traffic/schools/ } \\
\text { agricultural/industrial/ } \\
\text { residential/waste land }\end{array}$ \\
\hline Li et al. 2010 [32] & 28.3 & 123 & 2008 & $\begin{array}{l}\text { All areas within 5th } \\
\text { ring road }\end{array}$ & $\begin{array}{l}\text { Industrial/residential/commercial/ } \\
\text { traffic/parks/square/campuses }\end{array}$ \\
\hline Zheng et al. 2005 [35] & 28.8 & 600 & 2001 & $\begin{array}{l}\text { The city of Beijing, } \\
\text { including } 18 \text { district }\end{array}$ & $\begin{array}{l}\text { Crop/forest/orchard/urban green } \\
\text { spaces }\end{array}$ \\
\hline Chen et al. 2010 [15] & 35.4 & 80 & 2008 & $\begin{array}{l}\text { All areas within 5th } \\
\text { ring road }\end{array}$ & Roadside \\
\hline Xia et al. 2011 [23] & 39.5 & 120 & 2008 & $\begin{array}{l}\text { All areas within } 5 \text { th } \\
\text { ring road }\end{array}$ & $\begin{array}{l}\text { Business area/classical garden/ } \\
\text { culture and education area/public } \\
\text { green space/residential area/ } \\
\text { roadside area }\end{array}$ \\
\hline Chen et al. 2005 [31] & 66.2 & 30 & $2001-$ & $\begin{array}{l}\text { All areas within 4th } \\
\text { ring road }\end{array}$ & Urban park \\
\hline
\end{tabular}


The soil background value for Beijing is $25 \mathrm{mg} / \mathrm{kg}$, representing the natural $\mathrm{Pb}$ level in soil without human disturbance [36]. In our study, $27 \%$ of samples exceed the soil background value in Beijing, indicating that one fourth of the soil in Beijing is contaminated by $\mathrm{Pb}$. Moreover, the $\mathrm{Pb}$ contents of $11 \%$ of the samples are higher than $35 \mathrm{mg} / \mathrm{kg}$, exceeding the first criterion of the environment quality standards for soil to protect the ecological environment and sustain the natural soil background [37]. All of the samples are below the second criterion of the Chinese environment quality standard for soils (300 mg/kg), which represents the threshold for protecting human health. All of the soil $\mathrm{Pb}$ levels in our study are under $400 \mathrm{ppm}$, the USEPA's guideline for $\mathrm{Pb}$ in exposed play areas to protect children's health [38]. Comparisons with standards indicate that although the soil $\mathrm{Pb}$ content in some places in Beijing likely has a negative ecological impact, the overall health risk of soil $\mathrm{Pb}$ to humans in Beijing is low.

Compared with other cities that have been studied for soil $\mathrm{Pb}$ contamination, Beijing's soil $\mathrm{Pb}$ level is relatively low (Table 5). Bedrock sources, level of urbanization and industrialization, society development trajectory, and environmental regulations all affect $\mathrm{Pb}$ level in urban soils [39]. For example, Kerman has the highest soil mean $\mathrm{Pb}$ level because of mining and smelting operations [16]. The soil in Naples is derived from volcanic parent material, which contributes to its high $\mathrm{Pb}$ level [40]. Although Beijing is one of the oldest and largest cities in the word, its soil $\mathrm{Pb}$ level is relatively low due to bedrock sources, and the fact that Beijing has never hosted massive industrial activity.

Table 5. Urban soil $\mathrm{Pb}$ levels in different cities.

\begin{tabular}{|c|c|c|c|c|c|}
\hline City & $\begin{array}{c}\text { Pb-mean } \\
(\mathrm{mg} / \mathrm{kg})\end{array}$ & $\begin{array}{c}\text { Number } \\
\text { of } \\
\text { Samples }\end{array}$ & $\begin{array}{c}\text { Population } \\
\text { Density } \\
\left(\text { Inhabitants } / \mathbf{k m}^{2}\right) \\
\end{array}$ & $\begin{array}{l}\text { Study } \\
\text { Area } \\
\left(\mathbf{k m}^{2}\right) \\
\end{array}$ & Reference \\
\hline Beijing, China & 22 & 457 & 3,000 & 2,246 & This study \\
\hline Turku, Finland & 20 & 100 & 718 & 306.4 & Salonen and Korkka-Niemi 2007 [41] \\
\hline Tampa, USA & 47.3 & 106 & 1,146 & 2,078 & Hagan et al. $2012[24]$ \\
\hline Annaba, Algeria & 53.1 & 101 & 431.6 & 49 & Maas et al. 2010 [42] \\
\hline Calabria, Italy & 63.67 & 149 & 137 & 92 & Guagliardi et al. 2012 [43] \\
\hline Vienna, Austria & 64 & 286 & $4,002.2$ & 414.6 & Pfleiderer et al. 2012 [18] \\
\hline Galway, Ireland & 78.4 & 166 & 40.73 & 54 & Zhang 2006 [14] \\
\hline Bergen, Norway & 91 & 474 & 551 & 465 & Haugland et al. 2008 [10] \\
\hline Ibadan, Nigeria & 95.1 & 106 & 828 & 400 & Odewande and Abimbola 2008 [44] \\
\hline Oakland, USA & 109 & 112 & 1,934 & 202 & McClintock 2012 [20] \\
\hline Mexico, Mexico & 116 & 146 & 58 & 1,200 & Rodríguez-Salazar et al. 2011 [45] \\
\hline Seville, Spain & 156 & 52 & $5,002.9$ & 140 & Ruiz-Cortes et al. 2005 [21] \\
\hline Baltimore, USA & 231 & 122 & $2,635.2$ & 238.4 & Pouyat et al. 2008 [9] \\
\hline Naples, Italy & 262 & 173 & $8,182.6$ & 292 & Imperato et al. 2003 [40] \\
\hline Kerman, Iran & 925.7 & 38 & $1,617.7$ & 450 & Hamzeh et al. 2011 [16] \\
\hline
\end{tabular}

\subsection{Soil Pb Levels along the Urbanization Gradient}

Our results show that the soil $\mathrm{Pb}$ level in Beijing increases along the suburb-urban core gradient (Figure 3). The mean $\mathrm{Pb}$ levels are $19 \mathrm{mg} / \mathrm{kg}$ in the suburban area, $26 \mathrm{mg} / \mathrm{kg}$ in the transitional zone, 
and $30 \mathrm{mg} / \mathrm{kg}$ in the urban core (Table 3). This finding is consistent with previous studies indicating that the soil $\mathrm{Pb}$ level tends to be higher in more urbanized areas $[8,9,12]$.

While soil $\mathrm{Pb}$ is lower in the transitional zone than in the urban core, the difference is not statistically significant $(P=0.764)$ (Figure 3$)$. Three factors may contribute to $\mathrm{Pb}$ accumulation in the transitional zone. First, the transitional zone previously contained a number of industrial sites [26]. Although these sites were closed, $\mathrm{Pb}$ derived from industrial sources could have accumulated due to its high persistence. Second, the transitional zone has a higher density of urban residential land than the urban core and suburban area [26]. Frequent use of lead-based paints and household wastes [46] may contribute highly to the soil $\mathrm{Pb}$ accumulation in this area. Lastly, diesel trucks are allowed outside the 4th ring roads in Beijing, which is another source of soil $\mathrm{Pb}$ accumulation in the transitional area.

\subsection{Soil Pb Level by Land-Use Type}

Our results found that soil $\mathrm{Pb}$ levels tend to vary by land use (Table 3, Figure 4). We found higher $\mathrm{Pb}$ levels in industrial $(41.51 \mathrm{mg} / \mathrm{kg})$, roadside $(25 \mathrm{mg} / \mathrm{kg})$, and residential $(24 \mathrm{mg} / \mathrm{kg})$ areas, which echoes findings in Hangzhou [47] and Hong Kong [7]. Moreover, 40\%, 36\%, and 33\% of samples from roadside, residential, and industrial areas exceed the soil background of Beijing. These results indicate that emissions from industrial pollutants, traffic, and leaded paints are the main sources of soil $\mathrm{Pb}$ in Beijing.

We found that parks have the lowest soil $\mathrm{Pb}$ level $(16.85 \mathrm{mg} / \mathrm{kg})$, with the difference between parks and roadsides being statistically significant $(P=0.006)$ (Figure 4$)$. In contrast, several studies in Beijing found soil $\mathrm{Pb}$ levels in parks to be higher than those in other land uses [12,23]. This apparent contradiction is due to differences in the definition of "park". Parks in previous studies included historical sites, such as the Forbidden City and Temple of Heaven, which are primarily located in the urban core. The application of $\mathrm{Pb}$-containing paints and traffic emissions both contribute to $\mathrm{Pb}$ accumulation in such parks [31]. In contrast, parks in our study refer to neighborhood parks for recreational use (Figure 2d). Scattered throughout the entire city, these parks do not incur $\mathrm{Pb}$ from disproportionally high traffic emissions or from the paint used in ancient palaces.

We found that the soil $\mathrm{Pb}$ levels in roadsides are significantly higher than those in road greenbelts $(P=0.028)$ (Figure 4). Roadsides are in close contact to roads (Figure $2 b$ ) and could directly receive street dust with elevated levels of traffic pollutants, which is a major source of $\mathrm{Pb}$ in urban soil $[48,49]$. In addition, many road greenbelts were recently covered with garden soil, which normally has low $\mathrm{Pb}$ content. The trees and grass in road greenbelts may dilute traffic pollutants from street dust from reaching the soil and therefore decrease the soil $\mathrm{Pb}$ level in road greenbelts [32].

While many studies found that soils in industrial areas have significantly higher Pb levels $[7,18,19]$, our results indicate that the soil $\mathrm{Pb}$ level in industrial areas is within the range of that in other land uses. Dramatic land-use transformation, converting industrial area to other land use, could have masked differences in $\mathrm{Pb}$ content and lead to the observed similarity. Understanding the land change history will help explain the soil Pb patterns. For example, we found the highest $\mathrm{Pb}$ level $(291.98 \mathrm{mg} / \mathrm{kg})$ in suburban areas, which hosted the Shougang Construction Group, a steel production factory, beginning in 1919. 


\subsection{Soil Pb Level by Land-Use Type along the Urbanization Gradient}

Our results show that when the suburb-urban gradient is considered, only the transitional zone showed significant differences between soil $\mathrm{Pb}$ levels across land-use types $(P<0.001)$. In the transitional zone, multiple comparison of soil $\mathrm{Pb}$ level among land-use types shows that soil $\mathrm{Pb}$ is significantly higher in roadsides and residential areas than in parks and road greenbelts, swhile no obvious difference is found between other land uses (Figure 5).

Since 2000, Beijing has been experiencing rapid urban expansion, which has resulted in drastic land-use changes [26,50]. Vegetation increased between the 4th and 5th ring roads due to the creation of parks and road greenbelts [50,51]. We found that most of the road greenbelts and neighborhood parks, particularly those between the 4th and 5th ring roads, were newly built and filled with garden soils. This finding explains why the soil $\mathrm{Pb}$ in parks and road greenbelts is lower than that in other land uses. This finding illustrates how human intervention, especially soil restoration, can effectively reduce soil $\mathrm{Pb}$ and decrease human exposure to $\mathrm{Pb}[10,20,52]$.

Residential areas in the transitional zone have relatively high $\mathrm{Pb}$ levels for the following reasons: first, housing decoration waste containing $\mathrm{Pb}$-based paint is a major source of $\mathrm{Pb}$. Second, some residential areas in the transitional zone were built on former industrial sites and are affected by the past use of $\mathrm{Pb}$ in industrial activities. Lastly, household and yard waste (e.g., paper, plastics, cans, ceramics, toys, and waste batteries) and construction materials (e.g., lead pipes and solders) also increase the soil $\mathrm{Pb}$ level [46,53]. In addition, converting vegetation to residential and commercial areas is also occurring in suburban areas [51], albeit less intensively than in the transitional zone. Will soil $\mathrm{Pb}$ levels increase in the suburban area because of future increases in residential and traffic land use? Alternatively, will the soil $\mathrm{Pb}$ level remain relatively constant due to standards requiring the replacement of $\mathrm{Pb}$-based gasoline, paint, and other construction materials. Future studies may include time-series comparisons to answer these questions.

Some limitations exist in this study. First, we measured the total soil $\mathrm{Pb}$ content. Total soil $\mathrm{Pb}$ should not be confused with available $\mathrm{Pb}$, although they are closely related [54-56]. Second, our study has a limited sample size restrained by time and resources. In particular, we did not sample historical parks, which have been discussed by many researchers.

\section{Conclusions}

This study examined soil $\mathrm{Pb}$ levels in Beijing and found that it ranged from $<1 \mathrm{mg} / \mathrm{kg}$ to $292 \mathrm{mg} / \mathrm{kg}$, with a mean of $22 \mathrm{mg} / \mathrm{kg}$. We investigated soil $\mathrm{Pb}$ levels across an urbanization gradient and in different land uses. Consistent with previous studies, the soil $\mathrm{Pb}$ level increases from the suburban area to the transitional zone and then to the urban core. Comparing the results from previous studies, we found that the average degree of urbanization, the scope of the study area and the choice of sampling sites all have an important impact on the reported results. Studies focusing more on suburban areas of Beijing tend to report lower mean values of soil $\mathrm{Pb}$. Furthermore, we illustrated how the degree of urbanization may affect soil $\mathrm{Pb}$ levels among land-use types. While land use has an effect on soil $\mathrm{Pb}$ for Beijing as a whole, the impact was significant only in the transitional zone. Parks and road greenbelts tend to have lower soil $\mathrm{Pb}$, primarily due to soil restoration. Roadside and residential areas 
tend to have higher soil $\mathrm{Pb}$ because of traffic emission, leaded paints, and previous industrial contamination. The spatial patterns of soil $\mathrm{Pb}$ were examined in this study, which provides the foundation for future investigations of the temporal variation. Whether new technology and legislation banned $\mathrm{Pb}$-based paint, gasoline, and other construction material gradually mitigate the urbanization impact on soil $\mathrm{Pb}$ could be investigated through temporal studies focusing on soil $\mathrm{Pb}$ change by land use in rapidly urbanizing regions.

\section{Acknowledgments}

This research was supported by funds from the Special Foundation of the State Key Lab of Urban and Regional Ecology (Grant No. SKLURE2013-1-01) and the Foundation for the Recruitment Program of Global Experts of Beijing Normal University (Grant No. 257-107023). The authors sincerely thank Jianguo $\mathrm{Wu}$, Chunyang He, and Deyong Yu for their valuable input.

\section{Author Contributions}

Qizheng Mao and Keming Ma designed research; Qizheng Mao conducted research and analyzed data; Qizheng Mao and Ganlin Huang wrote the paper; Zexiang Sun provided the Figure 1; Qizheng Mao had primary responsibility for final content. All authors read and approved the final manuscript.

\section{Conflicts of Interest}

The authors declare no conflict of interest.

\section{References}

1. Tong, S.; von Schirnding, Y.E.; Prapamontol, T. Environmental lead exposure: A public health problem of global dimensions. Bull. WHO 2000, 78, 1068-1077.

2. Needleman, H.L.; Bellinger, D. The health effects of low level exposure to lead. Annu. Rev. Public Health 1991, 12, 111-140.

3. Needleman, H.L.; Gatsonis, C.A. Low-level lead exposure and the IQ of children. JAMA 1990, 263, 673-678.

4. Needleman, H.L.; Schell, A.; Bellinger, D.; Leviton, A.; Allred, E.N. The long-term effects of exposure to low doses of lead in childhood: An 11-year follow-up report. N. Engl. J. Med. 1990, 322, 83-88.

5. Mielke, H.W.; Reagan, P.L. Soil is an important pathway of human lead exposure. Environ. Health Perspect. 1998, 106, 217-229.

6. Mielke, H.W.; Gonzales, C.R.; Powell, E.; Jartun, M.; Mielke, P.W., Jr. Nonlinear association between soil lead and blood lead of children in metropolitan New Orleans, Louisiana: 2000-2005. Sci. Total Environ. 2007, 388, 43-53.

7. Chen, T.; Wong, J.; Zhou, H.; Wong, M. Assessment of trace metal distribution and contamination in surface soils of Hong Kong. Environ. Pollut. 1997, 96, 61-68. 
8. Lee, C.S.; Li, X.; Shi, W.; Cheung, S.C.; Thornton, I. Metal contamination in urban, suburban, and country park soils of Hong Kong: A study based on GIS and multivariate statistics. Sci. Total Environ. 2006, 356, 45-61.

9. Pouyat, R.; Yesilonis, I.; Szlavecz, K.; Csuzdi, C.; Hornung, E.; Korsós, Z.; Russell-Anelli, J.; Giorgio, V. Response of forest soil properties to urbanization gradients in three metropolitan areas. Landscape Ecol. 2008, 23, 1187-1203.

10. Haugland, T.; Ottesen, R.T.; Volden, T. Lead and polycyclic aromatic hydrocarbons (PAHs) in surface soil from day care centres in the city of Bergen, Norway. Environ. Pollut. 2008, 153, 266-272.

11. Gong, M.; Wu, L.; Bi, X.-Y.; Ren, L.-M.; Wang, L.; Ma, Z.-D.; Bao, Z.-Y.; Li, Z.-G. Assessing heavy-metal contamination and sources by GIS-based approach and multivariate analysis of urban-rural topsoils in Wuhan, central China. Environ. Geochem. Health 2010, 32, 59-72.

12. Wang, M.; Markert, B.; Chen, W.; Peng, C.; Ouyang, Z. Identification of heavy metal pollutants using multivariate analysis and effects of land uses on their accumulation in urban soils in Beijing, China. Environ. Monit. Assess. 2012, 184, 5889-5897.

13. Pouyat, R.; McDonnell, M. Heavy metal accumulations in forest soils along an urban-rural gradient in southeastern New York, USA. Water Air Soil Pollut. 1991, 57, 797-807.

14. Zhang, C. Using multivariate analyses and GIS to identify pollutants and their spatial patterns in urban soils in Galway, Ireland. Environ. Pollut. 2006, 142, 501-511.

15. Chen, X.; Xia, X.; Zhao, Y.; Zhang, P. Heavy metal concentrations in roadside soils and correlation with urban traffic in Beijing, China. J. Hazard. Mater. 2010, 181, 640-646.

16. Hamzeh, M.A.; Aftabi, A.; Mirzaee, M. Assessing geochemical influence of traffic and other vehicle-related activities on heavy metal contamination in urban soils of Kerman city, using a GIS-based approach. Environ. Geochem. Health 2011, 33, 577-594.

17. Schwarz, K.; Pickett, S.T.A.; Lathrop, R.G.; Weathers, K.C.; Pouyat, R.V.; Cadenasso, M.L. The effects of the urban built environment on the spatial distribution of lead in residential soils. Environ. Pollut. 2012, 163, 32-39.

18. Pfleiderer, S.; Englisch, M.; Reiter, R. Current state of heavy metal contents in Vienna soils. Environ. Geochem. Health 2012, 34, 665-675.

19. Sun, Y.; Zhou, Q.; Xie, X.; Liu, R. Spatial, sources and risk assessment of heavy metal contamination of urban soils in typical regions of Shenyang, China. J. Hazard. Mater. 2010, 174, 455-462.

20. McClintock, N. Assessing soil lead contamination at multiple scales in Oakland, California: Implications for urban agriculture and environmental justice. Appl. Geogr. 2012, 35, 460-473.

21. Ruiz-Cortes, E.; Reinoso, R.; Díaz-Barrientos, E.; Madrid, L. Concentrations of potentially toxic metals in urban soils of Seville: Relationship with different land uses. Environ. Geochem. Health 2005, 27, 465-474.

22. Pouyat, R.V.; Yesilonis, I.D.; Russell-Anelli, J.; Neerchal, N.K. Soil chemical and physical properties that differentiate urban land-use and cover types. Soil Sci. Soc. Am. J. 2007, 71, 1010-1019.

23. Xia, X.; Chen, X.; Liu, R.; Liu, H. Heavy metals in urban soils with various types of land use in Beijing, China. J. Hazard. Mater. 2011, 186, 2043-2050. 
24. Hagan, D.; Dobbs, C.; Timilsina, N.; Escobedo, F.; Toor, G.; Andreu, M. Anthropogenic effects on the physical and chemical properties of subtropical coastal urban soils. Soil Use Manag. 2012, $28,78-88$.

25. Beijing Statistical Yearbook 2013; Beijing Municipal Bureau of Statistics: Beijjng, China, 2013.

26. Kuang, W. Spatio-temporal patterns of intra-urban land use change in Beijing, China between 1984 and 2008. Chin. Geogr. Sci. 2012, 22, 210-220.

27. Sun, Y.; Zhuang, G.; Zhang, W.; Wang, Y.; Zhuang, Y. Characteristics and sources of lead pollution after phasing out leaded gasoline in Beijing. Atmos. Environ. 2006, 40, 2973-2985.

28. Tian, G.; Wu, J.; Yang, Z. Spatial pattern of urban functions in the Beijing metropolitan region. Habitat Int. 2010, 34, 249-255.

29. Microwave Assisted Acid Digestion of Siliceous and Organically Based Matrices, Method 3052. In Test Methods for Evaluating Solid Waste; USEPA: Washington DC, USA, 1995.

30. Wang, Z. Where is the 1st Ring Road in Beijing. Available online: http://www.zgghw.org/ $\mathrm{html} /$ xinwenjiaodian/guihuashidian/20110330/11055.html (accessed on 30 March 2011).

31. Chen, T.-B.; Zheng, Y.-M.; Lei, M.; Huang, Z.-C.; Wu, H.-T.; Chen, H.; Fan, K.-K.; Yu, K.; $\mathrm{Wu}, \mathrm{X}$; Tian, Q.-Z. Assessment of heavy metal pollution in surface soils of urban parks in Beijing, China. Chemosphere 2005, 60, 542-551.

32. Li , X.; Chen, T.; Lei, M.; Guo, Q.; Song, B.; Zhou, G.; Xie, Y. Accumulation of heavy metals of urban soils under different land uses in Beijing. Acta Sci. Circumstantiae 2010, 30, 2285-2293.

33. Hu, K.-L.; Zhang, F.-R.; Li, H.; Huang, F.; Li, B.-G. Spatial patterns of soil heavy metals in urban-rural transition zone of Beijing. Pedosphere 2006, 16, 690-698.

34. Lu, A.; Wang, J.; Qin, X.; Wang, K.; Han, P.; Zhang, S. Multivariate and geostatistical analyses of the spatial distribution and origin of heavy metals in the agricultural soils in Shunyi, Beijing, China. Sci. Total Environ. 2012, 425, 66-74.

35. Zheng, Y.; Chen, T.; Chen, H.; Zheng, G.; Luo, J. Lead accumulationin soils under different land use types in Beijing city. Acta Geogr. Sin. 2005, 60, 791-797.

36. Chen, T.; Zheng, Y.; Chen, H.; Zheng, G. Background Concentrations of Soil Heavy Metals in Beijing. Environ. Sci. 2004, 25, 117-122.

37. Soil Environmental Quality Standards in China; State Enviromental Protection Administration of China: Beijing, China, 1995.

38. USEPA. Identification of Dangerous Levels of Lead; Final Rule. Federal Register. 2001, 66, 1206-1240.

39. Luo, X.-S.; Yu, S.; Zhu, Y.-G.; Li, X.-D. Trace metal contamination in urban soils of China. Sci. Total Environ. 2012, 421, 17-30.

40. Imperato, M.; Adamo, P.; Naimo, D.; Arienzo, M.; Stanzione, D.; Violante, P. Spatial distribution of heavy metals in urban soils of Naples city (Italy). Environ. Pollut. 2003, 124, 247-256.

41. Salonen, V.-P.; Korkka-Niemi, K. Influence of parent sediments on the concentration of heavy metals in urban and suburban soils in Turku, Finland. Appl. Geochem. 2007, 22, 906-918.

42. Maas, S.; Scheifler, R.; Benslama, M.; Crini, N.; Lucot, E.; Brahmia, Z.; Benyacoub, S.; Giraudoux, P. Spatial distribution of heavy metal concentrations in urban, suburban and agricultural soils in a Mediterranean city of Algeria. Environ. Pollut. 2010, 158, 2294-2301. 
43. Guagliardi, I.; Cicchella, D.; Rosa, R. A Geostatistical approach to assess concentration and spatial distribution of heavy metals in urban soils. Water Air Soil Pollut. 2012, 223, 5983-5998.

44. Odewande, A.A.; Abimbola, A.F. Contamination indices and heavy metal concentrations in urban soil of Ibadan metropolis, southwestern Nigeria. Environ. Geochem. Health 2008, 30, 243-254.

45. Rodríguez-Salazar, M.T.; Morton-Bermea, O.; Hernández-Álvarez, E.; Lozano, R.; Tapia-Cruz, V. The study of metal contamination in urban topsoils of Mexico City using GIS. Environ. Earth Sci. 2011, 62, 899-905.

46. Harrison, R.M.; Laxen, D.P. Lead Pollution: Causes and Control; Chapman and Hall: London, UK, 1981; Volume 5.

47. Lu, S.G.; Bai, S.Q. Contamination and potential mobility assessment of heavy metals in urban soils of Hangzhou, China: Relationship with different land uses. Environ. Earth Sci. 2010, 60, $1481-1490$.

48. Cai, Q.Y.; Mo, C.H.; Li, H.Q.; Lu, H.; Zeng, Q.Y.; Li, Y.W.; Wu, X.L. Heavy metal contamination of urban soils and dusts in Guangzhou, South China. Environ. Monit. Assess. 2013, 185, 1095-1106.

49. Li, X.; Poon, C.-S.; Liu, P.S. Heavy metal contamination of urban soils and street dusts in Hong Kong. Appl. Geochem. 2001, 16, 1361-1368.

50. Kuang, W.; Liu, J.; Shao, Q.; Sun, C. Spatio-temporal patterns and driving forces of urban expansion in Beijing Central City since 1932. Geo-Information Science 2009, 4, 428-435.

51. Sun, X.; Wang, T.; Wu, J.; Ge, J. Change trend of vegetation cover in Beijing metropolitan region before and after the 2008 Olympics. Ying Yong Sheng Tai Xue Bao 2012, 23, 3133-3140.

52. Nielsen, J.B.; Kristiansen, J. Remediation of soil from lead-contaminated kindergartens reduces the amount of lead adhering to children's hands. J. Expo. Sci. Environ. Epidemiol. 2004, 15, 282-288.

53. Romieu, I.; Palazuelos, E.; Avila, M.H.; Rios, C.; Muñoz, I.; Jimenez, C.; Cahero, G. Sources of lead exposure in Mexico City. Environ. Health Perspect. 1994, 102, 384-389.

54. Johnson, D.L.; Bretsch, J.K. Soil lead and children's blood lead levels in Syracuse, NY, USA. Environ. Geochem. Health 2002, 24, 375-385.

55. Clark, H.F.; Brabander, D.J.; Erdil, R.M. Sources, sinks, and exposure pathways of lead in urban garden soil. J. Environ. Qual. 2006, 35, 2066-2074.

56. Morrison, D.; Lin, Q.; Wiehe, S.; Liu, G.; Rosenman, M.; Fuller, T.; Wang, J.; Filippelli, G. Spatial relationships between lead sources and children's blood lead levels in the urban center of Indianapolis (USA). Environ. Geochem. Health 2013, 35, 171-183.

(C) 2014 by the authors; licensee MDPI, Basel, Switzerland. This article is an open access article distributed under the terms and conditions of the Creative Commons Attribution license (http://creativecommons.org/licenses/by/3.0/). 